\title{
Hamdi Suat-Hulusi Behçet: An Affective Trainee - Tutor Relationship from Turkish Medical History
}

\author{
Hamdi Suat ve Hulusi Behçet: Tıp Tarihimizden Dokunaklı bir \\ Öğrenci - Hoca İlişkisi
}

\author{
Gülay SATAR', Selim KADIOǦLU² \\ 'Department of Dermatology, Acıbadem Adana Hospital, ADANA, TURKEY, \\ ${ }^{2}$ Department of History of Medicine and Ethics, Çukurova University, Faculty of Medicine, ADANA, TURKEY
}

\begin{abstract}
This article is about the trainee - tutor relationship between two eminent figures of Turkish medical history, namely Hamdi Suat Aknar (1873-1936) and Hulusi Behçet (1889-1948). Hamdi Suat Aknar was the pioneer of modern pathology in Turkey. Alongside his scientific achievements, he took educational activities seriously and exerted a great effort to train his students as proficient clinicians and physicians with good command of histology and histopathology. Hulusi Behçet met Hamdi Suat Aknar when he was a medical student and did not lose his contact with him ever since, even after becoming an internationally well-known scientist. Hulusi Behçet mentioned his tutor with gratitude at every opportunity and wrote a necrology full of sincerity after his death.
\end{abstract}

Key Words: Behcet disease, Pathology, Medical history, 20th cent., Turkey, Hamdi Suat Aknar, Hulusi Behçet

\begin{abstract}
ÖZ
$\mathrm{Bu}$ makalede, Türk tıp tarihinin iki seçkin siması olan Hamdi Suat Aknar (1873-1936) ve Hulusi Behçet (1889-1948) arasındaki hoca-öğrenci ilişkisi ele alınmıştır. Türkiyede çağdaş patolojinin öncüsü olan Hamdi Suat Aknar, bilimsel çalışmalarındaki başarısının yanı sıra eğitim etkinliklerini de ciddiyetle ele almış, öğrencilerinin iyi birer klinisyen olarak yetişmesinin ötesinde histolojiye ve histopatolojiye de hakim olması yönünde çaba göstermiştir. Hulusi Behçet öğrencisi olarak tanıştığı Hamdi Suat Aknar ile ilişkisini hiç kesmeyip, uluslararası ölçekte başarılı bir bilim adamı konumuna geldikten sonra da sürdürmüştür. Her firsatta şükran ve minnetle andığı hocasının ölümünden sonra da içtenlikli bir nekroloji yazmıştır.
\end{abstract}

Anahtar Sözcükler: Behçet hastalığı, Patoloji, Tip tarihi, 20. yüzyıl, Türkiye, Hamdi Suat Aknar, Hulusi Behçet

\section{INTRODUCTION}

While the identity of the physician is based on natural tendency and characteristics acquired by personal effort to a limited extent, it is actually a formation structured on information and skills gained by training. The result of this situation is that, physicians who are especially conscious about their professional identity and are at peace with it, feel a deep respect and a strong commitment to their tutors. Components as stated in the Hippocratic Oath in the tradition of medicine to hold their tutor as equal to their parents, give him a share of theirs if he is in need of money, and to teach his offspring this art, are indicators of this respect and commitment. Undoubtedly these positive feelings were more strong in the distant past when training was given as peer to peer communication and they were relatively weakened in today's world, which accepts that

Received : 17.03.2011

Accepted : 27.04.2011 training belongs to institutions, not people in a general framework with subjects of the curriculum in medical schools shared by a large training staff and lecturers facing students to a limited extent.

In the context of the trainee - tutor relationship between Hamdi Suat Aknar (1873-1936) (Figure 1) and Hulusi Behçet (1889-1948) (Figure 2), the approach of Hulusi Behçet to his tutor is a striking example of voicing such positive emotions in recent history of Turkish medicine (17). The professional life of Hulusi Behçet, one of the most famous names of Turkish medicine in the international arena, has been intersected for a few periods with Hamdi Suat who is the founder of the modern pathology in Turkey (8-10). Hulusi Behçet was in want of information from all areas of medicine during his studentship, realized the importance of the science of pathology and performed

Correspondence: Gülay SATAR

Department of Dermatology, Acıbadem Adana Hospital, ADANA, TURKEY

E-mail: gsatar@cu.edu.tr Phone: +90 5327636030 


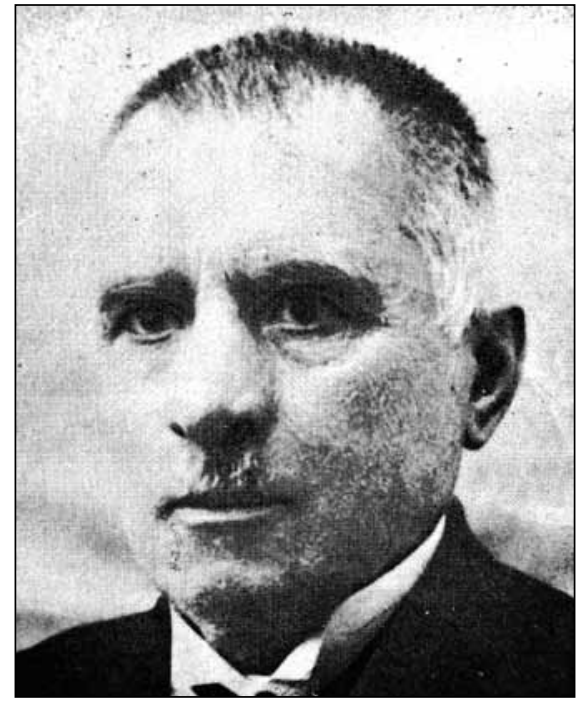

Figure 1: Hamdi Suat Aknar.

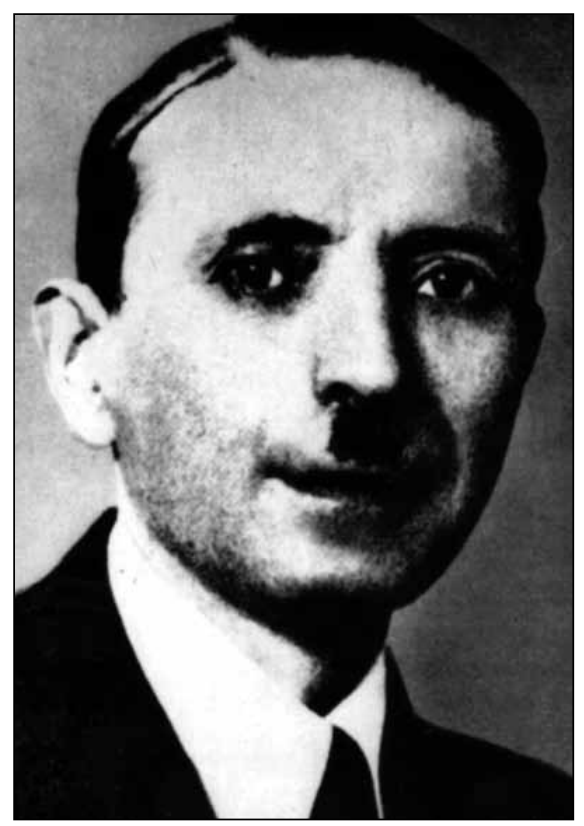

Figure 2: Hulusi Behçet.

intense theoretical and practical studies in this area. His interest continued in the specialization period as shown by his insistence on basing his clinical studies on a pathological basis. Besides his professional scientific interest in the area, Hulusi Behcet has mentioned his tutor with respect and gratitude at every opportunity.

Hulusi Behçet has been embedded into the history of Turkish dermatology by being a successful scientist and tutor as well as a prolific writer and dedicated publisher. He has mentioned Hamdi Suat in one of his important texts among his rich bibliography while he has written one text entirely about him (11). In the "Opening Lecture" of Istanbul University in 1933, Hulusi Behçet strongly emphasized the contributions of Hamdi Suat Aknar to Turkish medicine and dermatology at a time he was left outside the university with a questionable decision related to reform. This important speech was published several times in different publishing media (8-10). In the sincere necrology he wrote after the sudden loss of his tutor and included in the journal published by him, he has gracefully expressed the deep grief he felt as well as the feelings of love and respect for his tutor.

The section about Hamdi Suat in the "Opening Lecture" of Istanbul University in 1933 given by Hulusi Behçet and the full text entitled "Master Hamdi" published in Archives of Dermatology and Venerology Clinic are included below, preserving the language, expression and grammar of the period (8-11). The equivalents of some words and sequences of words and two historical information notes have been added into the text in the square brackets in order to provide easier understanding.

\section{OPENING LECTURE (THE SECTION ABOUT HAMDI SUAT)}

Hamdi Suat has been great of great service to the introduction of Turkish science in the world and resolving fine and delicate points of some rare diseases of the skin. I am proud of hearing, seeing and reading his unprecedented assistance to the dermatology discipline on behalf of being a Turk. I have learned the natural and disease-related changes of the skin by working with him for two years before becoming a physician and being in contact even after leaving school. My gratitude is endless.

\section{MASTER HAMDI}

Master Hamdi is the person that I had my first lesson in my discipline during school. How histology, anatomy and pathology were being studied in our time is known by those who lived during that period.

We were in the fourth grade even though we did not have any idea about histology. The revolution had taken place [military and civilian medical schools were united under the name of the Faculty of Medicine]. The Faculty was established and Master Hamdi had undertaken the courses in pathology and anatomy. Like our friends attending each discipline, three of us began to attend the pathological anatomy laboratory. Of course the first stage was to learn the microscopic formations of the anatomy of a healthy body. 
He regularly thought us anatomy. He showed the skin and its components and characteristics and successively went on to disease-related changes. We worked in his laboratory for two years and we did not lose our contact with each other after school. Thus, our relationship with Master Hamdi lasted 27-28 years overall.

During the period he was in the faculty, we visited him, observed some preparations and talked about disease factors need to be investigated. Finally he was appointed to our hospital. Here, our relationship continued in a more frequent and close manner. I rejoiced when I read his articles on some rare diseases of skin and cordially congratulated him. I responded humbly especially when I saw his articles on skin tumor.

The museum he established in the faculty was indeed a masterpiece. In fact, all the foreign professors visiting Istanbul congratulated him on this matter with consensus. Professor Favre was the latest one to arrive [Maurice Favre (1876-1954), French physician and dermatologist]. He was talking with Favre on paradenitis and while he was explaining what are the mainstays in disease-dependent anatomical changes, the professor, who discovered the disease, was appreciating the comments of Master Hamdi.

Master Hamdi was very industrious. His industriousness was accompanied by humility. He did not like to show-off at all. He would only express his satisfactions with his peculiar smiles. He valued his honor. He respected his elders, loved his employees with appreciation and his love was sincere and real.

I will not much prolong the text because many colleagues have mentioned about master Hamdi separately in booklets and various newspapers. I have suffered a lot and felt grief because of his death with the title of a student closest to him. I suffer a great hardship when I see the laboratories he reestablished in little time at our hospital (Yenibahce), preparations he has prepared and when I check his microscopy preparations and I most deeply feel sorry for his death at an age that he would be most productive. All my friends and his students are undoubtedly very sorry.

But my grief will continue all my life. After all, Master Hamdi is the one who reconciled me to my discipline, showing its subtlety in his microscopy and made me start to feel enjoyment from the subtlety of my discipline, who gave me this love during my work alongside him.
The foundation of my presence is that holy person. He is a great master. He is a valuable lecturer. $\mathrm{He}$ is a virtuous entity. What I feel is an intimate material and spiritual pain.

\section{CONCLUDING REMARK}

Following on these quotations showing the relationship between them and before the last review of the text, it will be appropriate to a make a series of reminders on and emphasize the professional-scientific identities of "trainee" and "tutor".

Clinical studies related to basic medical sciences spread over a wide range of topics have made Hulusi Behçet an internationally recognized scientist, and the disease he has defined and now known by his name has especially made him a well-known and remembered person today. Behçet's disease is a clinical table included in the interest areas of various medical disciplines such as immunology, rheumatology, ophthalmology and dermatology and is still not fully understood with no definitive treatment.

Hamdi Suat Aknar, who deserves to be qualified as the founder of pathology in a scientific sense in Turkey, is also a scientist who has drawn attention internationally with his studies. His pioneering work on cancer types and his efforts to spread awareness of the fight against cancer on a community scale are especially worth mentioning. His studies about rare diseases of the skin and skin tumors have made him a pioneer of dermatopathology in Turkey.

The fact that they are two important names of Turkish medicine makes the relationship between Hamdi Suat Aknar and Hulusi Behçet worth examining more closely. The respect, loyalty, devotion, gratitude paid and received by scientists who have demonstrated outstanding achievements in this relationship are an indicator that these positive emotional feelings are compatible with success and that self-focus is not a condition for success. From a different point of view, the writings of Hulusi Behcet about Hamdi Suat Aknar can also be read as the expression of how a medical lecturer positively impacts both the professional success of his student and his student's approach to him by doing his properly.

\section{ACKNOWLEDGEMENTS}

We would like to thank Prof. Dr. İlhan Tuncer for his encouraging and supporting approach and spiritual contribution to our work. 


\section{REFERENCES}

1. Seçkin S: Patolojinin tarihçesi, Hamdi Suat Aknar. [cited 2011 Jan 25]; Available from: http://www.patoloji.gen.tr/tarihce.htm

2. Hamdi Suad Aknar. [cited: 2008 Oct 08]; Available from: http:// turkkanser.org.tr/news.php?id=54

3. Yemni O: Ord. Prof. Dr. Hulusi Behçet. Deri Hastalıkları ve Frengi Kliniği Arşivi 1964, 1:58-59

4. Saylan T: Life story of Dr Hulusi Behçet. Yonsei Medical Journal 1997, 38:327-332 [cited: 2006 Mar 30]; Available from: http:// www.hulusibehcet.net/behcet.htm

5. Tüzün Y: Hulusi Behçet MD: February 20, 1889 to March 8, 1948. Clinics in Dermatology 2006, 24:548-550

6. Deri ve Frengi Kliniği Ailesi. Sayın Hocamız ve Mecmuamızın Kurucusu Ord. Prof. Dr. Hulusi Behçet’in Hayatı. Deri Hastalıkları ve Frengi Kliniği Arşivi 1948, 14:77-79
7. Satar G: Hulusi Behçet ve Behçet Hastalığının Tip Literatürüne Giriş Süreci. Adana: Çukurova University Healthcare Sciences Institute Ph.D. Thesis, 2009

8. Behçet H: Deri ve frengi hekimliği (Açılış dersi). Deri Hastalıkları ve Frengi Kliniği Arşivi 1934, 1:3-16

9. Behçet H: Deri Frengi Dersleri. İstanbul Üniversitesi Açllış Dersleri 1933-1934 and 1934-1935. İstanbul, Ahmed İhsan Basım Evi, 1935, 47-64

10. Behçet H: Açış Dersi (Osmanlıca metin). (Ed): Memişoğlu HR III. Ulusal Behçet Hastalığı Kongresi, 29-30 Kasım 1991. Adana, Çukurova Üniversitesi Matbaası, 1991

11. Behçet H: Hamdi Hoca. Deri Hastalıkları ve Frengi Kliniği Arşivi 1936, 3:1155-1156 